\title{
EARNINGS RESPONSE COEFFICIENTS IN THE GREEK MARKET
}

\author{
Dimitrios I. Maditinos ${ }^{1}, \check{Z ̌ e l j k o}$ Šević $^{2}$, Jelena Stankevičiené ${ }^{3}$, \\ Nikolaos Karakoltsidis ${ }^{4}$ \\ ${ }^{1,4}$ Kavala Institute of Technology, School of Business and Economics, \\ Department of Business Administration, Ag. Loukas, Kavala, 65404 Greece \\ ${ }^{2}$ Glasgow Caledonian University, Glasgow School for Business and Society, \\ Cowcaddens Road, Glasgow G4 0BA, United Kingdom \\ ${ }^{3}$ Department of Finance Engineering, Vilnius Gediminas Technical University, \\ Sauletekio al. 11, LT-10223 Vilnius, Lithuania \\ E-mails:12madi@teikav.edu.gr; ${ }^{2} z$ eljko.sevic@gcal.ac.uk; \\ 3jelena.stankeviciene@vgtu.lt (corresponding author); ${ }^{4}$ karakoltsidis@hotmail.com
}

Received 18 December 2010; accepted 15 February 2012

\begin{abstract}
The paper explores the relationship between accounting information and stock returns of the companies listed on the Athens Stock Exchange (ASE) in the period 19982008. Publicly available financial data on the companies included in the ASE during 1998-2008 have been collected and processed. The data sample consists of 245 companies and varies from 2,166 to 1,441 firm-year observations. The research methodology has been based on the extension of the model introduced by Kothari and Sloan (1992) and investigates whether the level of earnings divided by price at the beginning of the stock return period is associated with returns in the context of 'prices lead earnings' using annual and quarterly data. Cross-sectional regression analysis points to a significant relationship between earnings and returns on measurement windows of one year and longer. Similar results have been found in the case of a cumulative model where earnings are aggregated up to four years; however, relationship in the short measurement window up to three quarters has resulted in low earnings response coefficients.
\end{abstract}

Keywords: earnings response coefficient (ERC), stock returns, earnings, Athens stock exchange (ASE).

Reference to this paper should be made as follows: Maditinos, D. I; Šević, Ž.; Stankevičienè, J.; Karakoltsidis, N. 2013. Earnings response coefficients in the Greek market, Journal of Business Economics and Management 14(2): 414-431.

JEL Classification: G11, G14, G23.

\section{Introduction}

A fundamental issue of economics, finance and accounting involves the relation between the firm's reported earnings and its stock returns (Kormendi, Lipe 1987). Standard valuation models assume that price is the discount present value of future expected dividends or future cash flows. It is commonly assumed that, over long periods, re- 
ported accounting earnings are directly related to future dividends and cash flows. Ball, Brown (1968) numerous studies have attempted at identifying whether reported earnings contain information used by the market for assessing the value of the common stock of the firm.

In the late 1980s, researchers started investigating a new area - the earnings response coefficient (ERC) that is theoretically defined as "a change in the price induced by a one-dollar change in current earnings" (Collins, Kothari 1989) and typically measured as a slope coefficient in a regression of stock returns on unexpected earnings (Markowitz 1952, 1959). While the studies on the average price-to-earnings ratio (Stankevičiene, Gembickaja 2012) are concentrated on market reactions to earnings announcements, the studies on the earnings response coefficient are more interested in the nature of information about reported earnings and how they are related to firm valuation (Kormendi, Lipe 1987).

The main objective of this study is to analyse the relationship between accounting data and market price returns of the companies listed in the Athens Stock Exchange (ASE). More specifically, the article describes if there is a statistically significant earnings response coefficient of the companies listed in the ASE conducting annual cross-sectional and intertemporal regression analysis. The paper endorses and advances the methodology used by Kothari, Sloan (1992) and Jindrichovska (2001). The major findings of this study may contribute to various groups of people such as investors, corporations, regulators, educators and researchers.

The present study is organised as follows: section two consists of literature review discussing various relevant issues of research on the earnings response coefficient. The purpose of this work is to provide the basic theoretical and a detailed review of the earnings response coefficient (ERC). Moreover, it presents an empirical foundation for other studies and their implications. Section three examines the issues of research design and provides the research method, including a detailed discussion of the model employed. Section four contains the description of data and core results obtained from statistical analysis and focuses on answering the research methodology developed in the previous chapter. Section five discusses and summarises the findings of the study, including limitation on the results and suggestions for future research.

\section{Framing issues: theoretical considerations}

There are many approaches for how accounting data affect market price returns. Ball, Brown (1968) documented a positive statistical association between earnings surprises and stock returns around earnings announcements. A voluminous body of research (Beaver et al. 1980; Brown et al. 1987; Beaver 1989) has examined the role of accounting earnings in financial markets. In rather influential papers, that prompted further research, Easton, Zmijewski (1989), Collins, Kothari (1989) and Kormendi, Lipe (1987) empirically tested the last implication. Ohlson, Schroff (1992) confirmed that if investors used other information than that about earnings and dividends alone, there was a reason to prefer one specification over the other. Easton, Harris (1991) used a different method and examined earnings as an explanatory variable for return and confirmed the relation- 
ship between the level of earnings (scaled by price) and stock returns at the beginning of the period. The main difference in this study is that it has incorporated the level of and changes in earnings rather than only a change in earnings. Kothari (1992) and Kothari, Sloan (1992) also examined the strength of the relationship between price and earnings. On the contrary to the previous studies, they deflated earnings by the beginning-of-the year share price, including three leading period returns. They explored price-earnings regressions when 'prices lead earnings'.

Collins et al. (1994) incorporated up to three years of future earnings in their returnsearnings regressions and found the levels of explained return association that were higher when compared to regressions that only used contemporaneous earnings.

When employing the methodology proposed by Kothari, Sloan (1992) and a sample of UK companies, Donnelly, Walker (1995) supported the view that an increase in the ERCs realised by incorporating leading prices in return earnings relation were not specious. Kothari and Zimmerman (1995) provided an explanation of why return models were commonly preferred to price models. Nevertheless, return models have less serious econometric problems than price models (Liu, Thomas 2000). Consistent to Kothari, Zimmerman (1995) the results obtained by Martikainen et al. (1997) and Dumontier, Labelle (1998) in Finland and France respectively were presented.

Hayn (1995) noted that losses were very important when estimating return-earnings relation, because they were not expected to continue forever, since shareholders had a liquidation option. When loss observations are excluded, the association between returns and earnings becomes much stronger. This is supported by Finnish data collected by Martikainen et al. (1997) and Kallunki, Martikainen (1997).

Amir, Lev (1996) reported that the value of financial information was largely irrelevant in returns-earnings regressions, whereas that of nonfinancial information was highly relevant. Jermakowicz, Gornik-Tomaszewski (1998) evidenced a significant association between stock returns and accounting earnings and concluded that the annual earnings were an important element of the valuation process of a firm.

Jindrichovska (2001), following the methodology proposed by Kothari and Sloan (1992), reported that one-leading-year returns were as important as contemporaneous returns in terms of their sensitivity to annual changes in earnings. Jarmalaite (2002), on the basis of the methodology developed by the same Kothari, Sloan (1992), analysed the relationship between accounting data and stock price returns in the stock markets of Lithuania, Latvia and Estonia. The results suggested that the relationship between returns and earnings in Latvia seemed to be very similar to Estonia and Lithuania showing the weakest and Estonia showing the highest value relevance.

Myring et al. (2003) indicated that both Australian and United States markets reacted quite quickly to earnings releases. Similar results were reported by Liu and Thomas (2000) who investigated the role of analysts' earnings forecasts for explaining returns in Sweden. Suwardi (2009) discovered that in Jakarta Stock Exchange (JSX) the book value of net assets appeared to have a stronger relationship with the market value compared to the US studies that used similar estimated models. 
Kousenidis (2005) employed the Easton, Harris (1991) and found that the explanatory power of earnings for contemporaneous stock returns was not significant. Papadaki, Siougle (2007) confirmed a negative price-earnings ratio regarding firms suffering from loss and a positive price-earnings ratio as regards profitable firms.

Maditinos et al. (2007) provided evidence that there was a relation between EPS and stock market returns. The results concerning ROI and ROE were not significant. Moreover, they showed that the pair-wise regression of EPS and ROI best explained stock market returns in Greece, compared to the results provided by the combinations of EPS and ROE as well as by ROI and ROE.

Dimitropoulos, Asteriou (2009) concluded that the price model produced less biased ERCs than the return model but faced econometrical problems. The results showed the increased ability of the price and return models to explain better earnings-return relationship by providing highly significant earnings response coefficients. Furthermore, after correcting value-irrelevant noise in earnings, the return model yields highly significant ERCs. These results are consistent to Kothari, Zimmerman (1995), Martikainen et al. (1997) and Dumontier, Labelle (1998).

\section{Methodology}

According to Kothari, Sloan (1992) and Jindrichovska (2001), investors anticipate the numbers of future earnings at least some periods ahead. This is what is meant by "prices lead earnings". The reason for such a phenomenon is that the accounting system does not reveal information about future earnings in a timely manner while investors instantly adjust prices to their expectations of future profitability. This idea means that investors not only use information on past or current earnings numbers for stock valuation, but are assumed to use more information.

Kothari, Sloan (1992) presented a method for leading period returns to control the biased coefficients of return models and extended the return measurement window to several years before the fiscal year of interest, which resulted in higher earnings response coefficients. Figure 1 illustrates this idea.

This paper is aimed at examining the degree of the relationship between market prices and accounting data at both contemporaneous one-period return-earnings relation and leading period returns in the regression model. We examine if returns measured over one to four leading periods contain information about changes in annual earnings. Using the methodology suggested by Kothari, Sloan (1992), the degree of the relationship between price relatives (one plus the buy-and-hold return) and earnings-to-price ratio (earnings yield) is tested using a quarterly, yearly and intertemporal sample. It is employed the earnings level like Kothari, Sloan (1992) and Jindrichovska (2001) did, rather than change, deflated by price as the explanatory variable in the price earnings regression, which is motivated by the random walk time series property of annual earnings Ohlson (1995), and the evidence in Easton, Harris (1991) and Maditinos et al. (2007).

First, the model using contemporaneous earnings and prices is employed:

$$
\frac{P_{i t}}{P_{i t-\tau}}=a_{i}+\gamma_{1 i} \frac{X_{i t}}{P_{i t-\tau}}+e_{i t},
$$


where $X_{i t}$ is accounting earnings over period $t, P_{i t} / P_{i t-\tau}$ is one plus the buy-and-hold return inclusive of dividends over the period from the end of $t-\tau$ to the end of $t$. On the right-hand side, fraction $X_{i t} / P_{i t-\tau}$ represents the earnings-to-price ratio (earnings yield). The numerator consists of accounting earnings per share before extraordinary items for firm $i$ over the period from the end of $t-\tau$ to the end of $t$. Earnings are divided by the stock price at the beginning of period $t-\tau$ which is the same as the price at the end of the previous period. $\gamma_{1 i}$ is the ERC. The approach in this study has been applied to yearly as well as quarterly estimating windows.

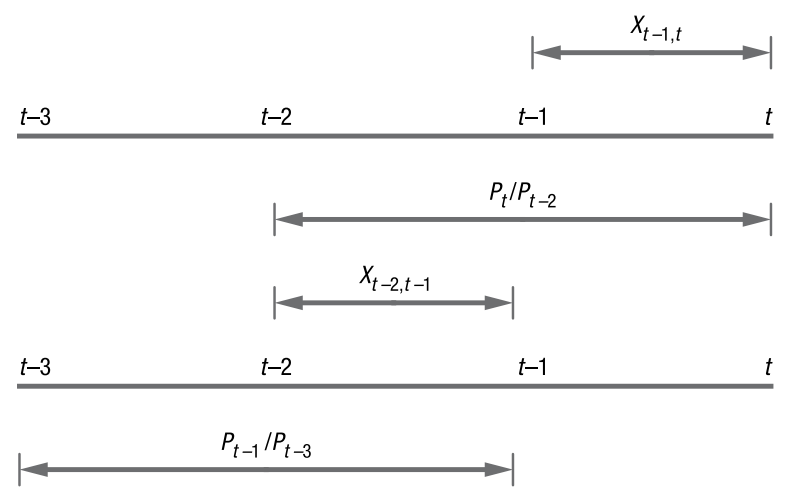

Fig. 1. Measurement intervals of earnings and returns Source: Kothari, Sloan (1992: 148)

Notes: Measurement intervals of earnings and returns in lead-lag price-earnings regressions based on two-year buy-and-hold returns, inclusive of dividends, regressed on annual earnings deflated by price at the beginning of the return measurement interval. The return measurement interval consists of the contemporaneous and one leading year.

Return observations are overlapping

After contemporaneous estimates, the estimation interval is lengthened and new coefficients are evaluated over a longer measurement interval up to four periods. In the next step, the independent variable is modified and earnings are summed for $(t-\tau)$ periods.

The model then changes to

$$
\frac{P_{i t}}{P_{i t-\tau}}=a_{i}+\gamma_{1 i} \frac{X_{i t-\tau, t}}{P_{i t-\tau}}+e_{i t} .
$$

As $\tau$ increases, it is more likely that information content reflected in $X_{i t}$, will be contained in the return over period $t-\tau$ to $t$. As a result, $\gamma_{1 i}$ (ERC) is expected to approach its predicted value of $(1+r)$. As Kothari and Sloan (1992) states, the multi-year return over period $t-\tau$ to $t$ reflects more information than that reflected in the one year earnings, $X_{i t}$. Furthermore, since this uncorrelated information resides in the dependent variable, it does not bias the estimated ERC, though the explanatory power of $\left(R^{2}\right)$ will be less than one. 


\section{Empirical results}

The sample is selected from the total number of Greek firms listed in the ASE. The sample period spans from 1998 to 2008 (we have chosen the period between 1998 and 2008 because it covers the market boom, the great recession in the period 1999-2000 and the integration of Greek economy to the European monetary system in 2001, since the Greek stock market has demonstrated considerable financial stability). The initial sample is eliminated by excluding all companies falling into the financial sector. 10 companies have been excluded from annual analysis because of a lack of annual observations. There are 245 publicly traded companies in the sample having a different number of participating years for each of them. These companies have given a total of 2.166 to $1.441 \mathrm{firm}$ year-observations. The accounting data have been obtained from the ASE data bank and the ICAP Company. Security prices have been extracted from the ASE database.

Descriptive statistics on earnings yield and price relatives computed from yearly data for the period 1998-2008 at measurement intervals ranging from one to four years are reported in Table 1. The number of observations varies from 2.166 to 1.441 . With reference to the collected data, sample mean, standard deviation, median, minimum and maximum values are obtained and summarized.

Table 1. Descriptive statistics

\begin{tabular}{lcccccc}
\hline Panel: 1 Cumulative earnings yield & Mean & St. dev. Median & Min. & Max. & $\mathrm{N}$ \\
\hline Length of the period & & & & & & \\
\hline 1 year & 0.128 & 0.310 & 0.048 & -1.640 & 5.836 & 2.166 \\
\hline 2 years & 0.253 & 0.547 & 0.108 & -2.849 & 6.845 & 1.910 \\
\hline years & 0.377 & 0.731 & 0.172 & -3.493 & 7.793 & 1.675 \\
\hline 4 years & 0.017 & 0.105 & 0.009 & -1.764 & 3.422 & 1.441 \\
\hline Panel: 2 Non-cumulative earnings yield & Mean & St. dev. Median & Min. & Max. & $\mathrm{N}$ \\
\hline Length of the period & & & & & & \\
\hline 1 year & 0.128 & 0.310 & 0.048 & -1.640 & 5.836 & 2.166 \\
\hline years & 0.131 & 0.430 & 0.055 & -4.747 & 7.083 & 1.910 \\
\hline 3 years & 0.129 & 0.433 & 0.052 & -4.093 & 9.437 & 1.675 \\
\hline 4 years & 0.114 & 0.344 & 0.044 & -3.993 & 4.239 & 1.441 \\
\hline $\begin{array}{l}\text { Panel: 3 Price relatives, including } \\
\text { dividend yield }\end{array}$ & Mean & St. dev. Median & Min. & Max. & $\mathrm{N}$ \\
\hline Length of the period & & & & & & \\
\hline 1 year & & & & & & \\
\hline 2 years & & 2.061 & 0.904 & 0.008 & 22.941 & 2.166 \\
\hline years & 1.803 & 3.870 & 0.839 & 0.009 & 55.631 & 1.910 \\
\hline 4 years & 1.389 & 2.485 & 0.813 & 0.007 & 52.487 & 1.675 \\
\hline
\end{tabular}

Notes: Earnings yield $\left(X_{i t-\tau, t} / P_{i t-\tau}\right)$ is annual earnings per share before extraordinary non-recurring items such as discontinued operations and special items over years $t-\tau$ to $t$ divided by the price at the beginning of the return measurement interval. Price relative $\left(P_{i t} / P_{i t-\tau}\right)$ is one plus buy-and-hold return inclusive of dividends over years $t-\tau$ to t. All earnings per share numbers and prices are adjusted for stock splits. $\mathrm{N}$ is the number of observations. 
The first and second panel contains descriptive statistics on earnings yield. In the first panel, both mean values and medians increase with time. Similar results were found by Kothari, Sloan (1992) and Jindrichovska (2001). However, the earnings yield of four year measurement window decreases. Moreover, variability measured by standard deviation is much higher than that presented in the study by Kothari and Sloan (1992). In Panel 2, a non-cumulative earnings yield shows an increasing mean and median over two years and a decreasing mean and median over four years. Jarmalaite (2002) reported similar results over a two year period. Our results are not consistent to those presented in the studies by Kothari, Sloan (1992) and Jindrichovska (2001). For example, Kothari, Sloan (1992) state that the mean and median earnings yield increases monotonically along with $\tau$.

Descriptive statistics on price relatives, including dividends on various measurement interval samples, is reported in the third panel of Table 1. An important point is that high variability that increases together with a measurement interval of two years, encounters a decrease in the following years. Table 2 displays the estimated ERC of the first cross-sectional regression model of the intertemporal (all years) sample. The estimated ERC shows higher sensitivity with leading period returns. The earnings response coefficient measured using ordinary least squares with common intercepts increases from $0.139(t=12.914)$ for contemporaneous estimates to $0.266(t=19.003)$ when returns over one leading-year is included to $0.317(t=22.867)$ for two leading-years and 0.321 $(t=22.136)$ for the four-year estimation window. The results indicate improvement in the ERC over the estimated period using annual data. All coefficients are significantly different from zero at the level of $5 \%$. The explanatory power measured by adjusted $R^{2}$ increases along with the window and ranges from 0.071 to 0.254 .

Table 2. Regressions of price relatives to earnings deflated by price

\begin{tabular}{|c|c|c|c|c|c|}
\hline \multicolumn{6}{|c|}{$P_{i t} / P_{i t-\tau}=a_{i}+\gamma_{1 i} X_{i t} / P_{i t-\tau}+e_{i t}$} \\
\hline \multicolumn{6}{|c|}{ Yearly Model } \\
\hline & & $\tau=1$ & $\tau=2$ & $\tau=3$ & $\tau=4$ \\
\hline \multirow[t]{9}{*}{ All Years } & Intercept & 0.317 & 0.674 & 0.695 & 0.605 \\
\hline & $\mathrm{t}$ & $(8.75)$ & $(14.105)$ & $(22.867)$ & $(11.638)$ \\
\hline & Sig. & 0.000 & 0.000 & 0.000 & 0.000 \\
\hline & ERC & 0.139 & 0.266 & 0.317 & 0.321 \\
\hline & $\mathrm{t}$ & $(12.914)$ & $(19.003)$ & $(22.867)$ & $(22.136)$ \\
\hline & Sig. & 0.000 & 0.000 & 0.000 & 0.000 \\
\hline & $\mathrm{R}^{2}$ & 0.072 & 0.16 & 0.238 & 0.255 \\
\hline & Adj $R^{2}$ & 0.071 & 0.159 & 0.238 & 0.254 \\
\hline & $\mathrm{N}$ & 2,166 & 1,910 & 1,675 & 1,441 \\
\hline
\end{tabular}

Notes: The interval of earnings measurement ranges from one to four years. Price relatives are contemporaneous for one year and periods that include leading years. Variables have been measured using OLS regression analysis of data for the period 1998-2008. Sample sizes vary from 2166 to 1441 firm year observations (t-statistic is significant at the level of $5 \%$ ). $\mathrm{N}$ is the number of observations in the regression. 
Similar conclusions are found in Collins, Kothari (1989), Easton et al. (1992) and Kothari, Sloan (1992). However, coefficients are rather small compared with Kothari, Sloan (1992) and Jindrichovska (2001) and their variance is not high. The basic conclusion is that the estimated ERCs are significant and show a stronger relation with stock returns as an increase in the leading periods. These results suggest that the model well describes the relationship between price relatives and accounting earnings in the ASE.

Table 3 shows the results received from the annual cross-sectional sample in the following way: in the case of contemporaneous estimates, eight out of eleven regressions (except the years 2000, 2005 and 2008) are statistically significant at the level of 0.05 according to $\mathrm{t}$-statistics. The ERCs range from $0.119(t=5.591)$ in 2001 to 0.048 $(t=2.207)$ in 2007 . The Adj. $\mathrm{R}^{2} \mathrm{~S}$ range from 0.137 to 0.016 each year respectively. For one leading year, all regressions are significant at the level of 0.05 . The ERCs vary between $0.261(t=5.659)$ in 2001 to $0.068(t=7.271)$ in 2008. In the four year estimation window, five out of eight coefficients (except years 2000, 2005 and 2008) are significant at the level of 0.05 according to t-statistics, ERCs range from $0.147(t=3.64)$ to 0.281 $(t=7.556)$ and Adj. $R^{2}$ s increase in all cases. Negative coefficients for a one-year window are puzzling and statistically insignificant and Adj. $R^{2}$ s are quite low. The results in this section suggest that the estimates of the earnings response coefficient, using Kothari, Sloan (1992) methodology, increase with the inclusion of leading-period returns in accordance with the tested hypothesis. Furthermore, they behave as the hypothesis predicts - increase along with the estimation window.

Table 3. The regression of price relatives to earnings deflated by price

\begin{tabular}{|c|c|c|c|c|c|}
\hline \multicolumn{6}{|c|}{$P_{i t} / P_{i t-\tau}=a_{i}+\gamma_{1 i} X_{i t} / P_{i t-\tau}+e_{i t}$} \\
\hline \multicolumn{6}{|c|}{ Yearly Model } \\
\hline & & $\tau=1$ & $\tau=2$ & $\tau=3$ & $\tau=4$ \\
\hline 1 & 2 & 3 & 4 & 5 & 6 \\
\hline \multirow[t]{9}{*}{1998} & Intercept & 0.726 & & & \\
\hline & $\mathrm{t}$ & $(7.688)$ & & & \\
\hline & Sig. & 0.000 & & & \\
\hline & ERC & 0.085 & & & \\
\hline & $\mathrm{t}$ & $(2.44)$ & & & \\
\hline & Sig. & 0.016 & & & \\
\hline & $\mathrm{R}^{2}$ & 0.052 & & & \\
\hline & Adj $R^{2}$ & 0.043 & & & \\
\hline & $\mathrm{N}$ & 110 & & & \\
\hline \multirow[t]{6}{*}{1999} & Intercept & 2.448 & 2.798 & & \\
\hline & $\mathrm{t}$ & $(18.078)$ & $(24.068)$ & & \\
\hline & Sig. & 0.000 & 0.000 & & \\
\hline & ERC & 0.21 & 0.196 & & \\
\hline & $\mathrm{t}$ & $(5.23)$ & $(4.894)$ & & \\
\hline & Sig. & 0.000 & 0.000 & & \\
\hline
\end{tabular}


Continue of Table 3

\begin{tabular}{|c|c|c|c|c|c|}
\hline 1 & 2 & 3 & 4 & 5 & 6 \\
\hline & $\mathrm{R}^{2}$ & 0.178 & 0.182 & & \\
\hline & $\operatorname{Adj} R^{2}$ & 0.172 & 0.174 & & \\
\hline & $\mathrm{N}$ & 128 & 110 & & \\
\hline \multirow[t]{9}{*}{2000} & Intercept & -1.07 & 1.262 & 1.537 & \\
\hline & $\mathrm{t}$ & $(-20.28)$ & (11.174) & $(15.441)$ & \\
\hline & Sig. & 0.000 & 0.000 & 0.000 & \\
\hline & ERC & -0.026 & 0.224 & 0.17 & \\
\hline & $\mathrm{t}$ & $(-2.003)$ & $(5.823)$ & $(4.224)$ & \\
\hline & Sig. & 0.047 & 0.000 & 0.000 & \\
\hline & $\mathrm{R}^{2}$ & 0.027 & 0.213 & 0.142 & \\
\hline & $\operatorname{Adj} R^{2}$ & 0.02 & 0.207 & 0.134 & \\
\hline & $\mathrm{N}$ & 149 & 128 & 110 & \\
\hline \multirow[t]{9}{*}{2001} & Intercept & 0.71 & -0.808 & 1.096 & 1.437 \\
\hline & $\mathrm{t}$ & $(0.875)$ & $(-5.095)$ & $(7.661)$ & $(12.845)$ \\
\hline & Sig. & 0.383 & 0.000 & 0.000 & 0.000 \\
\hline & ERC & 0.119 & 0.144 & 0.261 & 0.243 \\
\hline & $\mathrm{t}$ & $(5.591)$ & $(4.265)$ & $(5.659)$ & $(5.791)$ \\
\hline & Sig. & 0.000 & 0.000 & 0.000 & 0.000 \\
\hline & $\mathrm{R}^{2}$ & 0.142 & 0.104 & 0.203 & 0.235 \\
\hline & $\operatorname{Adj} R^{2}$ & 0.137 & 0.103 & 0.196 & 0.228 \\
\hline & $\mathrm{N}$ & 191 & 151 & 128 & 110 \\
\hline \multirow[t]{9}{*}{2002} & Intercept & -0.22 & -0.138 & -1.006 & 0.611 \\
\hline & $\mathrm{t}$ & $(-2.506)$ & $(-1.169)$ & $(5.559)$ & (4.161) \\
\hline & Sig. & 0.013 & 0.244 & 0.000 & 0.000 \\
\hline & ERC & 0.105 & 0.216 & 0.219 & 0.28 \\
\hline & $\mathrm{t}$ & (4.128) & $(7.014)$ & $(5.936)$ & (6.409) \\
\hline & Sig. & 0.000 & 0.000 & 0.000 & 0.000 \\
\hline & $\mathrm{R}^{2}$ & 0.079 & 0.207 & 0.191 & 0.246 \\
\hline & Adj $R^{2}$ & 0.074 & 0.202 & 0.186 & 0.24 \\
\hline & $\mathrm{N}$ & 202 & 191 & 151 & 128 \\
\hline \multirow[t]{6}{*}{2003} & Intercept & 0.236 & -0.048 & -0.682 & -1.1014 \\
\hline & $\mathrm{t}$ & $(4.509)$ & $(-0.541)$ & $(-5.49)$ & $(-5.96)$ \\
\hline & Sig. & 0.000 & 0.589 & 0.000 & 0.000 \\
\hline & ERC & 0.37 & 0.108 & 0.023 & 0.176 \\
\hline & $\mathrm{t}$ & $(2.242)$ & $(4.531)$ & $(0.684)$ & $(5.265)$ \\
\hline & Sig. & 0.026 & 0.000 & 0.495 & 0.000 \\
\hline
\end{tabular}


Continue of Table 3

\begin{tabular}{|c|c|c|c|c|c|}
\hline 1 & 2 & 3 & 4 & 5 & 6 \\
\hline & $\mathrm{R}^{2}$ & 0.023 & 0.093 & 0.02 & 0.157 \\
\hline & $\operatorname{Adj} R^{2}$ & 0.019 & 0.089 & -0.03 & 0.151 \\
\hline & $\mathrm{N}$ & 213 & 202 & 191 & 151 \\
\hline \multirow[t]{9}{*}{2004} & Intercept & -0.175 & 0.096 & 9.219 & -0.334 \\
\hline & $\mathrm{t}$ & $(-2.487)$ & $(1.12)$ & $(-1.791)$ & $(-2.39)$ \\
\hline & Sig. & 0.014 & 0.264 & 0.075 & 0.018 \\
\hline & ERC & 0.051 & 0.105 & 0.152 & 0.201 \\
\hline & $\mathrm{t}$ & $(2.41)$ & (3.946) & $(4.617)$ & $(5.891)$ \\
\hline & Sig. & 0.017 & 0.000 & 0.000 & 0.000 \\
\hline & $\mathrm{R}^{2}$ & 0.026 & 0.069 & 0.096 & 0.155 \\
\hline & Adj $R^{2}$ & 0.021 & 0.064 & 0.092 & 0.151 \\
\hline & $\mathrm{N}$ & 221 & 213 & 202 & 191 \\
\hline \multirow[t]{9}{*}{2005} & Intercept & 0.046 & 0.259 & 0.534 & -0.163 \\
\hline & $\mathrm{t}$ & $(0.664)$ & $(2.604)$ & $(4.895)$ & $(-1.108)$ \\
\hline & Sig. & 0.507 & 0.010 & 0.000 & 0.269 \\
\hline & ERC & -0.014 & 0.17 & 0.23 & 0.147 \\
\hline & $\mathrm{t}$ & $(-0.592)$ & (5.653) & $(6.706)$ & (3.64) \\
\hline & Sig. & 0.504 & 0.000 & 0.000 & 0.000 \\
\hline & $\mathrm{R}^{2}$ & 0.002 & 0.128 & 0.176 & 0.062 \\
\hline & Adj $R^{2}$ & -0.003 & 0.124 & 0.172 & 0.058 \\
\hline & $\mathrm{N}$ & 231 & 221 & 213 & 201 \\
\hline \multirow[t]{9}{*}{2006} & Intercept & 0.547 & 0.732 & 0.689 & 0.954 \\
\hline & $\mathrm{t}$ & $(9.385)$ & $(8.973)$ & $(6.685)$ & $(8.625)$ \\
\hline & Sig. & 0.000 & 0.000 & 0.000 & 0.000 \\
\hline & ERC & 0.102 & 0.144 & 0.222 & 0.278 \\
\hline & $\mathrm{t}$ & $(5.368)$ & (5.316) & (7.247) & $(8.13)$ \\
\hline & Sig. & 0.000 & 0.000 & 0.000 & 0.000 \\
\hline & $\mathrm{R}^{2}$ & 0.11 & 0.11 & 0.194 & 0.239 \\
\hline & Adj $R^{2}$ & 0.106 & 0.106 & 0.19 & 0.236 \\
\hline & $\mathrm{N}$ & 235 & 231 & 221 & 212 \\
\hline \multirow[t]{6}{*}{2007} & Intercept & 0.239 & 0.759 & 0.992 & 0.926 \\
\hline & $\mathrm{t}$ & (3.5) & $(9.329)$ & (9.793) & $(7.813)$ \\
\hline & Sig. & 0.001 & 0.000 & 0.000 & 0.000 \\
\hline & ERC & 0.048 & 0.148 & 0.212 & 0.281 \\
\hline & $\mathrm{t}$ & $(2.207)$ & (5.342) & (5.989) & $(7.556)$ \\
\hline & Sig. & 0.028 & 0.000 & 0.000 & 0.000 \\
\hline
\end{tabular}


End of Table 3

\begin{tabular}{cccccc}
\hline 1 & 2 & 3 & 4 & 5 & 6 \\
\hline & $\mathrm{R}^{2}$ & 0.02 & 0.11 & 0.135 & 0.207 \\
\hline & Adj R & 0.016 & 0.106 & 0.132 & 0.204 \\
\hline $\mathrm{N}$ & 235 & 234 & 231 & 221 \\
\hline 2008 & Intercept & -0.975 & 0.732 & 0.687 & -0.333 \\
\hline $\mathrm{t}$ & $(-11.027)$ & $(8.994)$ & $(6.696)$ & $(-3.618)$ \\
\hline Sig. & 0.000 & 0.000 & 0.000 & 0.000 \\
\hline $\mathrm{ERC}$ & -0.032 & 0.144 & 0.221 & 0.042 \\
\hline $\mathrm{t}$ & $(-1.281)$ & $(5.338)$ & $(7.271)$ & $(-3.618)$ \\
\hline & Sig. & 0.217 & 0.000 & 0.000 & 0.177 \\
\hline $\mathrm{R}^{2}$ & 0.007 & 0.01 & 0.022 & 0.008 \\
\hline Adj R & 0.003 & 0.006 & 0.018 & 0.004 \\
\hline & $\mathrm{N}$ & 235 & 228 & 228 & 227 \\
\hline
\end{tabular}

Notes: The interval of earnings measurement ranges from one to four years. Price relatives are contemporaneous for one year and periods that include leading years. Variables have been measured using OLS regression analysis of data for the period 1998-2008 (t-statistic is significant at the level of 5\%). $\mathrm{N}$ is the number of observations in the regression.

After the completion of annual estimates, quarterly results were assessed. The estimation of ordinary least squares is used for estimating the common slope coefficient. However, the quarterly model did not yield high explanatory power.

Table 4 reports the results (all years) of the cumulative model (3.2) that represents the cross-sectional OLS regression of aggregated earnings divided by the price of the return measurement window and price relatives over the period of one up to four years. According to Kothari and Sloan (1992) and Jindrichovska (2001), when earnings are aggregated and the earnings measurement window increases, the variation of results should be smaller. The results show that all ERC coefficients are significant at the level of 0.05 and grow as the estimation window increases up to three periods. In the case of contemporaneous estimates, explanatory power is very low (the same as in Table 4) and the ERC is $0.139(t=12.914)$. When the period of leading years is examined, it rises to $0.275(t=18.160)$ and $0.328(t=21.704)$ for two and three years respectively. The results are consistent to those identified by Kothari and Sloan (1992) and Jindrichovska (2001), despite higher ERCs. Generally, the model indicates the increased ability of the return model to explain the relationship between published earnings and stock prices with the inclusion of one leading-period return, as the earnings response coefficient substantially increases and converges toward the predicted value. However, the relation does not hold in the longer run $(\tau=4)$ as the ERC drops to $0.321(t=21.111)$.

Table 5 shows the results of the annual cross-sectional sample. In all cases, except years 2001 and 2008, the ERC is highly significant at the level of 0.05 and follows a similar pattern as that for the full year sample. As the hypothesis predicts, the ERC increases 
as returns from leading years are included. Furthermore, the Adj. $\mathrm{R}^{2}$ improves when the periods are led forward in all cases. These results are consistent with those found in Kothari and Sloan (1992) and Jindrichovska (2001) and indicate that the cumulative model explains the relationship between price relatives and earnings as the theoretical framework suggests.

Table 4. The regression of price relatives to cumulative earnings deflated by price

\begin{tabular}{|c|c|c|c|c|c|}
\hline \multicolumn{6}{|c|}{$P_{i t} / P_{i t-\tau}=a_{i}+\gamma_{1 i} X_{i t-\tau, \mathrm{t}} / P_{i t-\tau}+e_{i t}$} \\
\hline \multicolumn{6}{|c|}{ Cumulative Yearly Model } \\
\hline & & $\tau=1$ & $\tau=2$ & $\tau=3$ & $\tau=4$ \\
\hline \multirow[t]{9}{*}{ All Years } & Intercept & 0.317 & 0.027 & 0.264 & 0.027 \\
\hline & $\mathrm{t}$ & $(8.75)$ & $(11.554)$ & $(7.727)$ & $(0.821)$ \\
\hline & Sig. & 0.000 & 0.000 & 0.000 & 0.412 \\
\hline & ERC & 0.139 & 0.275 & 0.328 & 0.321 \\
\hline & $\mathrm{t}$ & $(12.914)$ & $(18.160)$ & $(21.704)$ & $(21.111)$ \\
\hline & Sig. & 0.000 & 0.000 & 0.000 & 0.000 \\
\hline & $\mathrm{R}^{2}$ & 0.072 & 0.237 & 0.220 & 0.237 \\
\hline & $\operatorname{Adj} R^{2}$ & 0.071 & 0.147 & 0.220 & 0.236 \\
\hline & $\mathrm{N}$ & 2,166 & 1,910 & 1,675 & 1,441 \\
\hline
\end{tabular}

Notes: The interval of earnings measurement ranges from one to four years. Price relatives are contemporaneous for one year and periods that include leading years. Data on earnings are cumulative. Variables have been measured using OLS regression analysis of data for the period 1998-2008. Sample sizes vary from 2,166 to 1,441 firm year observations ( $\mathrm{t}$-statistic is significant at the level of $5 \%$ ). $\mathrm{N}$ is the number of observations in the regression.

Table 5. The regression of price relatives to cumulative earnings deflated by price

\begin{tabular}{|c|c|c|c|c|c|}
\hline \multicolumn{6}{|c|}{$P_{i t} / P_{i t-\tau}=a_{i}+\gamma_{1 i} X_{i t-\tau, \mathrm{t}} / P_{i t-\tau}+e_{i t}$} \\
\hline \multicolumn{6}{|c|}{ Cumulative Yearly Model } \\
\hline & & $\tau=1$ & $\tau=2$ & $\tau=3$ & $\tau=4$ \\
\hline 1 & 2 & 3 & 4 & 5 & 6 \\
\hline \multirow[t]{9}{*}{1998} & Intercept & 0.726 & & & \\
\hline & $\mathrm{t}$ & $(7.688)$ & & & \\
\hline & Sig. & 0.000 & & & \\
\hline & ERC & 0.085 & & & \\
\hline & $\mathrm{t}$ & $(2.44)$ & & & \\
\hline & Sig. & 0.016 & & & \\
\hline & $\mathrm{R}^{2}$ & 0.052 & & & \\
\hline & $\operatorname{Adj} R^{2}$ & 0.043 & & & \\
\hline & $\mathrm{N}$ & 110 & & & \\
\hline
\end{tabular}


Continue of Table 5

\begin{tabular}{|c|c|c|c|c|c|}
\hline 1 & 2 & 3 & 4 & 5 & 6 \\
\hline \multirow[t]{9}{*}{1999} & Intercept & 2.448 & 2.683 & & \\
\hline & $\mathrm{t}$ & $(18.078)$ & $(25.451)$ & & \\
\hline & Sig. & 0.000 & 0.000 & & \\
\hline & ERC & 0.21 & 0.239 & & \\
\hline & $\mathrm{t}$ & (5.23) & (4.383) & & \\
\hline & Sig. & 0.000 & 0.000 & & \\
\hline & $\mathrm{R}^{2}$ & 0.178 & 0.151 & & \\
\hline & Adj $R^{2}$ & 0.172 & 0.143 & & \\
\hline & $\mathrm{N}$ & 128 & 110 & & \\
\hline \multirow[t]{9}{*}{2000} & Intercept & -1.07 & 1.177 & 1.391 & \\
\hline & $\mathrm{t}$ & $(-20.28)$ & $(12.847)$ & $(20.096)$ & \\
\hline & Sig. & 0.000 & 0.000 & 0.000 & \\
\hline & ERC & -0.026 & 0.270 & 0.233 & \\
\hline & $\mathrm{t}$ & $(-2.003)$ & $(6.595)$ & $(5.102)$ & \\
\hline & Sig. & 0.047 & 0.000 & 0.000 & \\
\hline & $\mathrm{R}^{2}$ & 0.027 & 0.257 & 0.194 & \\
\hline & Adj $R^{2}$ & 0.02 & 0.251 & 0.187 & \\
\hline & $\mathrm{N}$ & 149 & 128 & 110 & \\
\hline \multirow[t]{9}{*}{2001} & Intercept & 0.71 & -1.480 & 0.591 & 0.894 \\
\hline & $\mathrm{t}$ & $(0.875)$ & $(-15.166)$ & $(7.260)$ & $(12.587)$ \\
\hline & Sig. & 0.383 & 0.000 & 0.000 & 0.000 \\
\hline & ERC & 0.119 & -0.080 & 0.170 & 0.013 \\
\hline & $\mathrm{t}$ & $(5.591)$ & $(-0.338)$ & $(5.080)$ & $(1.540)$ \\
\hline & Sig. & 0.000 & 0.736 & 0.000 & 0.126 \\
\hline & $\mathrm{R}^{2}$ & 0.142 & 0.001 & 0.172 & 0.022 \\
\hline & Adj $R^{2}$ & 0.137 & -0.006 & 0.163 & 0.012 \\
\hline & $\mathrm{N}$ & 191 & 151 & 128 & 110 \\
\hline \multirow[t]{9}{*}{2002} & Intercept & -0.22 & -0.554 & -1.576 & -0.031 \\
\hline & $\mathrm{t}$ & $(-2.506)$ & $(-7.154)$ & $(-14.786)$ & $(-0.382)$ \\
\hline & Sig. & 0.013 & 0.000 & 0.000 & 0.703 \\
\hline & ERC & 0.105 & 0.140 & 0.149 & 0.199 \\
\hline & $\mathrm{t}$ & $(4.128)$ & $(5.678)$ & $(5.035)$ & $(5.605)$ \\
\hline & Sig. & 0.000 & 0.000 & 0.000 & 0.000 \\
\hline & $\mathrm{R}^{2}$ & 0.079 & 0.146 & 0.145 & 0.200 \\
\hline & Adj $R^{2}$ & 0.074 & 0.141 & 0.140 & 0.193 \\
\hline & $\mathrm{N}$ & 202 & 191 & 151 & 128 \\
\hline \multirow[t]{4}{*}{2003} & Intercept & 0.236 & -0.080 & -0.396 & -1.389 \\
\hline & $\mathrm{t}$ & $(4.509)$ & $(-0.977)$ & $(-5.347)$ & $(-14.295)$ \\
\hline & Sig. & 0.000 & 0.330 & 0.000 & 0.000 \\
\hline & ERC & 0.037 & 0.137 & 0.168 & 0.170 \\
\hline
\end{tabular}


Continue of Table 5

\begin{tabular}{|c|c|c|c|c|c|}
\hline 1 & 2 & 3 & 4 & 5 & 6 \\
\hline & $\mathrm{t}$ & $(2.242)$ & $(4.546)$ & $(6.457)$ & $(5.903)$ \\
\hline & Sig. & 0.026 & 0.000 & 0.000 & 0.000 \\
\hline & $\mathrm{R}^{2}$ & 0.023 & 0.094 & 0.181 & 0.190 \\
\hline & Adj $R^{2}$ & 0.019 & 0.089 & 0.176 & 0.184 \\
\hline & $\mathrm{N}$ & 213 & 202 & 191 & 151 \\
\hline \multirow[t]{9}{*}{2004} & Intercept & -0.175 & 0.030 & -0.288 & -0.707 \\
\hline & $\mathrm{t}$ & $(-2.487)$ & $(0.407)$ & $(-2.905)$ & $(-8.875)$ \\
\hline & Sig. & 0.014 & 0.685 & 0.004 & 0.000 \\
\hline & ERC & 0.051 & 0.120 & 0.228 & 0.205 \\
\hline & $\mathrm{t}$ & $(2.41)$ & $(3.805)$ & $(5.189)$ & $(6.630)$ \\
\hline & Sig. & 0.017 & 0.000 & 0.000 & 0.000 \\
\hline & $\mathrm{R}^{2}$ & 0.026 & 0.064 & 0.119 & 0.189 \\
\hline & $\operatorname{Adj} R^{2}$ & 0.021 & 0.060 & 0.114 & 0.184 \\
\hline & $\mathrm{N}$ & 221 & 213 & 202 & 191 \\
\hline \multirow[t]{9}{*}{2005} & Intercept & 0.046 & 0.083 & 0.233 & -0.158 \\
\hline & $\mathrm{t}$ & $(0.664)$ & $(0.947)$ & $(2.384)$ & $(-1.610)$ \\
\hline & Sig. & 0.507 & 0.345 & 0.005 & 0.109 \\
\hline & ERC & -0.014 & 0.162 & 0.253 & 0.315 \\
\hline & $\mathrm{t}$ & $(-0.592)$ & $(4.34) 2$ & $(5.577)$ & $(6.179)$ \\
\hline & Sig. & 0.504 & 0.000 & 0.000 & 0.002 \\
\hline & $\mathrm{R}^{2}$ & 0.002 & 0.079 & 0.128 & 0.161 \\
\hline & Adj $R^{2}$ & -0.003 & 0.075 & 0.124 & 0.157 \\
\hline & $\mathrm{N}$ & 231 & 221 & 213 & 201 \\
\hline \multirow[t]{9}{*}{2006} & Intercept & 0.547 & 0.683 & 0.487 & 0.544 \\
\hline & $\mathrm{t}$ & $(9.385)$ & $(10.198)$ & $(6.219)$ & $(7.424)$ \\
\hline & Sig. & 0.000 & 0.000 & 0.000 & 0.000 \\
\hline & ERC & 0.102 & 0.186 & 0.295 & 0.346 \\
\hline & $\mathrm{t}$ & $(5.368)$ & $(6.028)$ & $(7.367)$ & $(7.562)$ \\
\hline & Sig. & 0.000 & 0.000 & 0.000 & 0.000 \\
\hline & $\mathrm{R}^{2}$ & 0.11 & 0.137 & 0.199 & 0.213 \\
\hline & $\operatorname{Adj} R^{2}$ & 0.106 & 0.133 & 0.195 & 0.210 \\
\hline & $\mathrm{N}$ & 235 & 231 & 221 & 212 \\
\hline \multirow[t]{9}{*}{2007} & Intercept & 0.239 & 0.709 & 0.811 & 0.579 \\
\hline & $\mathrm{t}$ & $(3.5)$ & $(10.760)$ & (11.484) & $(7.485)$ \\
\hline & Sig. & 0.001 & 0.000 & 0.000 & 0.000 \\
\hline & ERC & 0.048 & 0.189 & 0.276 & 0.379 \\
\hline & $\mathrm{t}$ & $(2.207)$ & $(6.147)$ & $(6.468)$ & $(7.916)$ \\
\hline & Sig. & 0.217 & 0.000 & 0.000 & 0.000 \\
\hline & $\mathrm{R}^{2}$ & 0.02 & 0.140 & 0.157 & 0.222 \\
\hline & Adj $R^{2}$ & 0.016 & 0.136 & 0.153 & 0.219 \\
\hline & $\mathrm{N}$ & 235 & 235 & 231 & 221 \\
\hline
\end{tabular}


End of Table 5

\begin{tabular}{cccccc}
\hline 1 & 2 & 3 & 4 & 5 & 6 \\
\hline 2008 & Intercept & -0.983 & -0.704 & 0.403 & -0.365 \\
\hline $\mathrm{t}$ & $(-11.106)$ & $(-8.618)$ & $(-8.793)$ & $(-5.932)$ \\
\hline Sig. & 0.000 & 0.000 & 0.000 & 0.000 \\
\hline ERC & -0.033 & 0.045 & 0.098 & 0.094 \\
\hline $\mathrm{t}$ & $(-1.281)$ & $(1.000)$ & $(2.611)$ & $(2.365)$ \\
\hline Sig. & 0.000 & 0.187 & 0.010 & 0.019 \\
\hline $\mathrm{R}^{2}$ & 0.007 & 0.008 & 0.171 & 0.024 \\
\hline Adj R & 0.003 & 0.003 & 0.025 & 0.020 \\
\hline $\mathrm{N}$ & 235 & 228 & 228 & 227 \\
\hline
\end{tabular}

Notes: The interval of earnings measurement ranges from one to four years. Price relatives are contemporaneous for one year and periods that include leading years. Variables have been measured using OLS regression analysis of data for the period 1998-2008 (t-statistic is significant at the level of 5\%). $\mathrm{N}$ is the number of observations in the regression.

As the obtained results indicate, the first model using annual data and the cumulative model well explain the relationship between earnings and returns. The explanatory power of each model increases along with the measurement window, and therefore provides useful information to ASE investors.

\section{Concluding remarks}

The main aim of the paper was to analyze the relationship between accounting earnings and returns on the Greek market. It has been conducted using data on published earnings and stock prices covering the period from 1998 to 2008 and focusing on earnings response coefficients estimated using returns measured over a long interval (one quarter up to four years). The estimates have been calculated for the annual cross-sectional and intertemporal sample relying on the methodology proposed by Kothari and Sloan (1992). According to empirical results, the estimates of the earnings response coefficient are sensitive to the inclusion of leading-period returns.

As for the first model, empirical evidence from cross-sectional regression analysis suggest that information provided by earnings-to-price ratios is of some value relevance for explaining market price returns in ASE, i.e. the estimated earnings response coefficient is found to be significant to the leading periods and increased when more leading periods are included. The explanatory power of the model increases from 7.1 to $25.4 \%$. Consistent with the studies by Kothari and Sloan (1992) and Jindrichovska (2001), the estimated ERC is significant and shows a stronger relation with stock returns as the leading periods increase, i.e. prices contain information about the earnings of listed firms. The obtained results are similar to those received annually and recommend that prices anticipate earnings and therefore provide useful information to ASE. For a short estimation of the window of up to three-quarters, the model did not behave as expected.

The relationship between contemporaneous earnings-to-price ratios and price relatives is not statistically significant. The quarterly model (all years and annual) has revealed 
that, with the inclusion of more than one leading period, the ERC increases as the theory predicts. However, the explanatory power of the model remains rather low in order to be considered adequate. As the results depict, the cumulative model provides higher and more significant ERCs when the measurement interval is widened to three years. However, it drops when the measurement interval is four years. The explanatory power of the model increases from 7.1 to $23.6 \%$. These results are comparable with those presented in the study by Kothari and Sloan (1992). An additional interpretation of the findings is that stock prices reflect investors' view that current earnings provide them with information about future earnings and future returns considering the firms listed in ASE, i.e. the market responds quickly to new information and anticipates earnings. Within this interpretation, the results suggest that the Athens stock exchange market demonstrates some features of semi-strong efficiency, and stock prices incorporate all publicly available information.

The present study can be further extended for examining the relationship between returns and accounting earnings in a longer period, as well as other econometric methods can be used for improving the final results. For further analysis, it would be motivating to take control over permanent and transitory components of earnings and evaluate the information content of other financial statements additionally to earnings in order to acknowledge value-relevant events not recognized in the earnings of the period under consideration. Moreover, the examination of the effect of losses (negative earnings) in the earnings-returns relation would be a prolific path for future research.

\section{References}

Amir, E.; Lev, B. 1996. Value-relevance of nonfinancial information: the wireless communications industry, Journal of Accounting and Economics 22(1/3): 3-30.

http://dx.doi.org/10.1016/S0165-4101(96)00430-2

Ball, R.; Brown, P. 1968. An empirical evaluation of accounting income numbers, Journal of Accounting Research 6(2): 159-178. http://dx.doi.org/10.2307/2490232

Beaver, W.; Lambert, R.; Morse, D. 1980. The information content of security prices, Journal of Accounting and Economics 2(1): 3-28. http://dx.doi.org/10.1016/0165-4101(80)90013-0

Brown, L.; Griffin, P.; Hagerman, R.; Zmijewski, M. 1987. An evaluation of alternative proxies for the market's expectation of earnings, Journal of Accounting and Economics 9(2): 159-193. http://dx.doi.org/10.1016/0165-4101(87)90004-8

Collins, D. W.; Kothari, S. P. 1989. An analysis of intertemporal and cross-sectional determinants of earnings response coefficients, Journal of Accounting and Economics 11(2/3): 143-181.

http://dx.doi.org/10.1016/0165-4101(89)90004-9

Collins, D. W.; Kothari, S. P.; Shanken, J.; Sloan, R. 1994. Lack of timeliness versus noise as explanations for low contemporaneous return-earnings association, Journal of Accounting and Economics 18(3): 289-324. http://dx.doi.org/10.1016/0165-4101(94)90024-8

Dimitropoulos, P.; Asteriou, D. 2009. The relationship between earnings and stock returns: empirical evidence from the Greek capital market, International Journal of Economics and Finance 1(1): 40-50.

Donnelly, R.; Walker, M. 1995. Share price anticipation of earnings and the effect of earnings persistence and firm size, Journal of Business, Finance and Accounting 22(1): 5-18.

http://dx.doi.org/10.1111/j.1468-5957.1995.tb00668.x 
Dumontier, P.; Labelle, R. 1998. Accounting earnings and firm valuation: the French case, The European Accounting Review 7(2): 163-183. http://dx.doi.org/10.1080/096381898336439

Easton, P. D.; Harris, T. S.; Ohlson, J. 1992. Aggregate accounting earnings can explain most security returns: the case of long return intervals, Journal of Accounting and Economics 15(2/3): 119-42. http://dx.doi.org/10.1016/0165-4101(92)90015-T

Easton, P. D.; Harris, T. S. 1991. Earnings as an explanatory variable for returns, Journal of Accounting Research 29(1): 19-36. http://dx.doi.org/10.2307/2491026

Easton, P.; Zmijewski, M. 1989. Cross-sectional variation in the stock market response to accounting earnings announcements, Journal of Accounting and Economics 11(2/3): 49-36.

Hayn, C. 1995. The information content of losses, Journal of Accounting and Economics 20(2): 125-53. http://dx.doi.org/10.1016/0165-4101(95)00397-2

Jarmalaite, N. 2002. The relationship between accounting numbers and returns in the Baltic Stock Markets, CERT Discussion paper No 2002/06. Edinburgh: Heriot-Watt University.

Jermakowicz, E. K.; Gornik-Tomaszewski, S. 1998. Information content of earnings in the Emerging Capital Market: evidence from Warsaw Stock Exchange, Multinational Finance Journal 2(4): 245-267.

Jindrichovska, I. 2001. The relationship between accounting numbers and returns: some empirical evidence from the Emerging Market of Czech Republic, The European Accounting Review 10(1): 107-131.

Kallunki, J.; Martikainen, T. 1997. The lead-lag structure of stock returns and accounting earnings: implications to the returns-earnings relation in Finland, International Review of Financial Analysis 6(1): 37-47. http://dx.doi.org/10.1016/S1057-5219(97)90018-1

Kormendi, R.; Lipe, R. 1987. Earnings innovations, earnings persistence and stock returns, Journal of Business 60(3): 323-345. http://dx.doi.org/10.1086/296400

Kothari, S. P. 1992. Price-earnings regressions in the presence of prices leading earnings: earnings level versus change specifications and alternative deflators, Journal of Accounting and Economics 15(2/3): 173-302. http://dx.doi.org/10.1016/0165-4101(92)90017-V

Kothari, S. P.; Sloan, R. 1992. Information in prices about future earnings: implications for earnings response coefficients, Journal of Accounting and Economics 15(2/3): 143-171.

http://dx.doi.org/10.1016/0165-4101(92)90016-U

Kothari, S. P.; Zimmerman, J. L. 1995. Price and return models, Journal of Accounting and Economics 20(2): 155-192. http://dx.doi.org/10.1016/0165-4101(95)00399-4

Kousenidis, D. 2005. Earnings-returns relation in Greece: some evidence on the size effect and on the life-cycle hypothesis, Managerial Finance 31(2): 24-54.

http://dx.doi.org/10.1108/03074350510769488

Liu, J.; Thomas, J. 2000. Stock returns and accounting earnings, Journal of Accounting Research 38(1): 71-102. http://dx.doi.org/10.2307/2672923

Maditinos, D.; Šević, Z.; Chatzoglou, P.; Theriou, G. 2007. Earnings as an explanatory tool in explaining stock market returns and the use of Easton and Harris (1991) model: the case of Greece, in International Scientific Conference, Contemporary Challenges of Theory and Practice in Economics. Belgrade, 26-29 September, 2007, Proceedings. Belgrade: Faculty of Economics of the University of Belgrade Publishing Centre, Čugura Print, 2007, 93-106. ISBN 978-86403-0843-4.

Markowitz, H. M. 1959. Portfolio Selection: Efficient Diversification of Investments. New York: Wiley.

Markowitz, H. M. 1952. Portfolio selection, Journal of Finance 7(1): 77-91. 
Martikainen, T.; Kallunki, J.; Perttunen, J. 1997. Finnish earnings response coefficients: the information content of losses, The European Accounting Review 6(1): 69-81.

http://dx.doi.org/10.1080/096381897336872

Myring, M., Shortridge, R. T.; Alst, L. V. 2003. The relationship between returns and unexpected earnings: a comparison of Australia and the United States, Journal of Business and Economics Research 1(8): 71-79.

Ohlson, J. 1995. Earnings, book values, and dividends in equity valuation, Contemporary Accounting Research 11(2): 661-687. http://dx.doi.org/10.1111/j.1911-3846.1995.tb00461.x

Ohlson, J. A.; Shroff, P. K. 1992. Changes versus levels in earnings as explanatory variables for returns: some theoretical considerations, Journal of Accounting Research 30(2): 210-226.

http://dx.doi.org/10.2307/2491124

Papadaki, A.; Siougle, G. 2007. Value relevance of price, earnings and book values in the Athens Stock Exchange, Managerial Finance 33(5): 309-320.

http://dx.doi.org/10.1108/03074350710739597

Stankevičienè, J.; Gembickaja, N. 2012. Market behaviour: case studies of NASDAQ OMX Baltic, Business, Management and Education 10(1): 110-127.

Suwardi, E. 2009. The dynamic relationship between accounting numbers and share prices on the Jakarta Stock Exchange, International Review of Business Research Papers 5(5): 16-24.

Dimitrios I. MADITINOS is an Assoc. Professor of Information Technology, Finance and Financial Modelling at Kavala Institute of Technology, School of Business and Economics (Greece). His research interests are in financial modelling, performance measurement systems, investors' behaviour, financial information systems, ERPs, electronic commerce and e-business.

Željko ŠEVIĆ is a Professor at Glasgow Caledonian University, Dean of Caledonian Business School (UK). His current research interests are in the public sector reform in Japan and Vietnam (on-going projects), and accounting reform in the public sector with the particular emphasis on the use of management accounting in public sector restructuring, and the design of effective financial/fiscal information system.

Jelena STANKEVIČIENĖ is an Assoc. Professor in the Department of Finance Engineering at Vilnius Gediminas Technical University (Lithuania). Her main research topics include assets and liability management, regulation of financial institution, financial management for value creation, value engineering.

Nikolaos KARAKOLTSIDIS hold an MSc in Finance and Financial Information Systems from the Business School, Greenwich University, London, UK. His research interests are in financial modelling, performance measurement systems, investors' behaviour, financial information systems, ERPs, electronic commerce and e-business. 